\title{
Pathogenic NOTCH3 Variants Are Frequent Among the Korean General Population
}

Chul-Hoo Kang, MD,* Young Mee Kim, PhD, * Yang-Ji Kim, MS, Su-Jeong Hong, MS, Do Yoon Kim, BS, Hyun Goo Woo, MD, PhD, Young Ree Kim, MD, PhD, Joong-Goo Kim, MD, Jung Seok Lee, MD, Mi Hee Kong, MD, PhD, Hyeon Ju Kim, MD, and Jay Chol Choi, MD, PhD

Neurol Genet 2021;7:e639. doi:10.1212/NXG.0000000000000639

\section{Abstract}

\section{Objective}

This study aimed to determine the frequency of pathogenic $\mathrm{NOTCH} 3$ variants among Koreans.

\section{Methods}

In this cross-sectional study, we queried for pathogenic NOTCH3 variants in 2 Korean public genome databases: the Korean Reference Genome Database (KRGDB) and the Korean Genome Project (Korea1K). In addition, we screened the 3 most common pathogenic NOTCH3 variants (p.Arg75Pro, p.Arg544Cys, and p.Arg578Cys) for 1,000 individuals on Jeju Island, where the largest number of patients with cerebral autosomal dominant arteriopathy with subcortical infarcts and leukoencephalopathy (CADASIL) have been reported in Korea.

\section{Results}

The pathogenic NOTCH3 variant (p.Arg544Cys) was found in $0.12 \%$ of sequences in the KRGDB, and 3 pathogenic variants (p.Arg75Pro, p.Arg182Cys, and p.Arg544Cys) were present in $0.44 \%$ of the Korea1K database. Of the 1,000 individuals on Jeju Island, we found 2 cysteine-altering NOTCH3 variants (p.Arg544Cys variant in 9 and p.Arg578Cys in 1 individual) in $1.00 \%$ of the participants (95\% confidence interval: $0.48 \%-1.83 \%)$. The presence of cysteine-altering NOTCH3 variants was significantly associated with a history of stroke ( $p<$ $0.001)$.

\section{Discussion}

Pathogenic NOTCH3 variants are frequently found in the general Korean population. Such a high prevalence of pathogenic variants could threaten the brain health of tens of thousands to hundreds of thousands of older adults in Korea.

\author{
Correspondence \\ Dr. Choi \\ jaychoi@jejunu.ac.kr
}


Cerebral autosomal dominant arteriopathy with subcortical infarcts and leukoencephalopathy (CADASIL) was known as a rare genetic disorder with an estimated prevalence of 2-5/ $100,000 .{ }^{1,2}$ However, recent genomic database research clearly indicates an estimated global mutation prevalence of 3.4/1,000, much higher than that estimated previously. ${ }^{3}$ In particular, the East or South Asian regions showed the highest frequency of cysteine-altering $\mathrm{NOTCH} 3$ mutations with a prevalence of 9.0-11.7/1,000 individuals. This study aimed to determine the frequency of pathogenic NOTCH3 variants among Koreans.

\section{Methods}

\section{Korean Public Genome Database Query}

We queried for pathogenic NOTCH3 variants associated with CADASIL in 2 publicly available Korean genome databases: the Korean Reference Genome Database (KRGDB) and the Korean Genome Project (Korea1K). ${ }^{4,5}$ The KRGDB was established by the Korean National Institute of Health and contains whole-genome data for 1,722 participants from various cohorts. The Korea1K data set included wholegenome data of 1,094 healthy individuals, mostly from the Ulsan metropolitan region located in the southern part of the Korean peninsula. ANNOVAR bioinformatics software was used for annotating any rare nonsynonymous variants, including missense, inframe insertion/deletion, frameshift, start gain/loss, stop gain/loss, and splice site variants in the NOTCH3 gene. ${ }^{6}$ In this study, a minor allele frequency $<0.01$ was defined as a rare variant. Among the rare variants retrieved from the database, we defined the variant as pathogenic if it was associated with CADASIL and classified as pathogenic or likely pathogenic in ClinVar (ncbi.nlm.nih.gov/clinvar/).

\section{Screening for NOTCH3 Variants Among 1,000 Individuals Living on Jeju Island}

Of the 4,350 anonymized genomic DNA samples, a randomly selected 1,000 samples with their health information were provided by the Biobank of Jeju National University Hospital, a member of the Korea Biobank Network. This study was approved by the Institutional Review Board of Jeju National University Hospital (IRB File No. JEJUNUH 2020-09-006). Informed consent was obtained at the time of DNA donation to the Biobank. We screened the 3 most frequently found NOTCH3 mutations on Jeju Island: p.Arg75Pro (c.244G>C),
p.Arg544Cys (c.1630>T), and p.Arg578Cys (c.1732C>T). Other detailed information for the PCR, sequencing, and statistical analysis was provided as Supplemental Material, links.lww.com/NXG/A495.

\section{Results}

\section{Pathogenic NOTCH3 Variants in 2 Korean Public Genome Databases}

Three pathogenic NOTCH3 variants associated with CADASIL, p.Arg75Pro (c.224G>C), p.Arg182Cys (c.544C >T), and p.Arg544Cys (c.1630C $>\mathrm{T})$, were found in 2 Korean public genome databases. In the KRGDB with 1,722 participants, only the p.Arg544Cys variant was identified with a carrier frequency of $0.12 \%$. Three pathogenic variants (p.Arg75Pro, p.Arg182Cys, and p.Arg544Cys) were present in the KorealK database with 1,094 individuals, and the carrier frequencies were $0.22,0.11$, and $0.11 \%$, respectively. Only the p.Arg544Cys variant was discovered in common (Table 1).

\section{Screening Pathogenic NOTCH3 Variants in 1,000 Individuals on Jeju Island}

Of 1,000 individuals on Jeju Island, 3 had a history of stroke, and $6.6 \%$ had a family history of stroke. We found 2 cysteinealtering $\mathrm{NOTCH} 3$ variants in $1.00 \%$ of the participants with a $95 \%$ confidence interval of $0.48-1.83 \%$ (p.Arg 544 Cys mutation in 9 individuals and p.Arg578Cys in 1). Compared with individuals without pathogenic $\mathrm{NOTCH} 3$ variants, those with the variants were more likely to have a history of stroke $(p<$ 0.001) (Table 2). Of the 10 individuals with pathogenic variants, 2 participants underwent a brain MRI examination (eTable 3, links.lww.com/NXG/A495 and Figure).

\section{Discussion}

A recent study from Taiwan reported a very high prevalence of cysteine-altering NOTCH3 variants among Taiwanese (9/ 1,000 ), and the study also suggested that the cysteine-altering variant resulted in a 3.40-fold increased risk for stroke and even an 11.05-fold increased risk for small-vessel stroke. ${ }^{7}$ In line with the Taiwanese study, this study suggested a high prevalence of pathogenic NOTCH3 variants among the general Korean population, with an estimated number of carriers ranging from $1.2 / 1,000$ to $4.4 / 1,000$. On Jeju Island, located

Table 1 Prevalence of Pathogenic NOTCH3 Variants in 2 Korean Public Genome Databases and 1,000 Individuals Living on Jeju Island

\begin{tabular}{llll}
\hline & KRGDB & \multicolumn{1}{l}{ Korea 1K } & Jeju screening study \\
\hline Number of participants & 1,722 & 1,094 & 1,000 \\
\hline NOTCH3 variant frequency & p.Arg544Cys (0.12\%) & $\begin{array}{l}\text { p.Arg75Pro (0.22\%) } \\
\text { p.Arg544Cys (0.11\%) }\end{array}$ & $\begin{array}{l}\text { p.Arg544Cys (0.90\%) } \\
\text { p.Arg578Cys (0.10\%) }\end{array}$ \\
\hline
\end{tabular}

Abbreviation: KRGDB = Korean Reference Genome Database. 
Table 2 Baseline Characteristics of the Jeju Participants

\begin{tabular}{|c|c|c|c|c|}
\hline & No variants $(n=990)$ & Variants $(n=10)$ & Total $(\mathrm{N}=\mathbf{1 , 0 0 0})$ & $p$ Value \\
\hline \multicolumn{5}{|l|}{ Demographic } \\
\hline Age, y & $49.9 \pm 11.3$ & $51.9 \pm 14.5$ & $49.9 \pm 11.3$ & 0.573 \\
\hline Male & $454(45.4)$ & $6(60.0)$ & $460(46.0)$ & 0.373 \\
\hline Height, cm & $164.6 \pm 8.5$ & $165.8 \pm 6.3$ & $164.6 \pm 8.5$ & 0.661 \\
\hline Weight, kg & $64.1 \pm 11.6$ & $63.1 \pm 8.3$ & $64.1 \pm 11.6$ & 0.771 \\
\hline \multicolumn{5}{|l|}{ Vascular risk factors } \\
\hline Hypertension & $4(0.4)$ & $0(0.0)$ & $4(0.4)$ & 0.841 \\
\hline DM & $0(0.0)$ & $0(0.0)$ & $0(0.0)$ & - \\
\hline Hyperlipidemia & $38(3.8)$ & $0(0.0)$ & $38(3.8)$ & 0.528 \\
\hline Smoking & $256(25.9)$ & $2(20.0)$ & $258(25.8)$ & 0.674 \\
\hline \multicolumn{5}{|l|}{ Medical history } \\
\hline Stroke & $0(0.0)$ & $3(30.0)$ & $3(0.3)$ & $<0.001$ \\
\hline Ischemic heart disease & $4(0.4)$ & $0(0.0)$ & $4(0.4)$ & 0.841 \\
\hline \multicolumn{5}{|l|}{ Family history } \\
\hline Stroke & $65(6.6)$ & $1(10.0)$ & $66(6.6)$ & 0.664 \\
\hline \multicolumn{5}{|l|}{ Laboratory finding } \\
\hline Systolic blood pressure, $\mathrm{mm} \mathrm{Hg}$ & $117.8 \pm 11.5$ & $118.7 \pm 10.2$ & $117.8 \pm 11.5$ & 0.800 \\
\hline Diastolic blood pressure, $\mathrm{mm} \mathrm{Hg}$ & $74.1 \pm 8.2$ & $74.9 \pm 8.9$ & $74.1 \pm 8.2$ & 0.756 \\
\hline White blood cell, $\mathrm{k} / \mathrm{mm}^{3}$ & $5.4 \pm 1.5$ & $4.5 \pm 0.7$ & $5.4 \pm 1.5$ & 0.045 \\
\hline Hemoglobin, g/dL & $14.0 \pm 1.7$ & $14.1 \pm 1.4$ & $14.0 \pm 1.7$ & 0.943 \\
\hline Platelet count, $\mathrm{k} / \mathrm{mm}^{3}$ & $250.3 \pm 56.2$ & $240.6 \pm 33.9$ & $250.2 \pm 56.1$ & 0.586 \\
\hline BUN, mg/dL & $12.0 \pm 3.6$ & $12.1 \pm 3.2$ & $12.0 \pm 3.6$ & 0.950 \\
\hline Creatinine, mg/dL & $0.9 \pm 0.2$ & $1.0 \pm 0.2$ & $0.9 \pm 0.2$ & 0.935 \\
\hline Estimated GFR (IDMS-MDRD), $\mathrm{mL} / \mathrm{min} / 1.73 \mathrm{~m}^{2}$ & $93.1 \pm 15.8$ & $95.3 \pm 15.7$ & $93.1 \pm 15.8$ & 0.812 \\
\hline Fasting glucose, $\mathrm{mg} / \mathrm{dL}$ & $89.9 \pm 8.8$ & $94.1 \pm 11.7$ & $90.0 \pm 8.9$ & 0.140 \\
\hline $\mathrm{HbA1C}, \%$ & $5.4 \pm 0.4$ & $5.4 \pm 0.4$ & $5.4 \pm 0.4$ & 0.970 \\
\hline CRP, mg/dL & $0.13 \pm 0.43$ & $0.03 \pm 0.01$ & $0.13 \pm 0.43$ & 0.486 \\
\hline Homocysteine, mg/dL & $8.5 \pm 2.8$ & $8.1 \pm 1.2$ & $8.5 \pm 2.8$ & 0.765 \\
\hline Total cholesterol, mg/dL & $190.4 \pm 26.1$ & $172.0 \pm 31.3$ & $190.2 \pm 26.2$ & 0.028 \\
\hline LDL cholesterol, mg/dL & $115.9 \pm 24.0$ & $110.3 \pm 28.7$ & $115.9 \pm 24.0$ & 0.494 \\
\hline HDL cholesterol, mg/dL & $59.2 \pm 14.3$ & $48.0 \pm 9.5$ & $59.0 \pm 14.3$ & 0.014 \\
\hline Triglyceride, mg/dL & $82.9 \pm 36.8$ & $77.0 \pm 38.3$ & $82.8 \pm 36.8$ & 0.614 \\
\hline
\end{tabular}

Abbreviations: BUN, blood urea nitrogen; DM, diabetes mellitus; GFR, glomerular filtration rate; HDL, high-density lipoprotein; IDMS-MDRD, isotope dilution mass spectrometry-the modification of diet in renal disease; LDL, low-density lipoprotein.

Data are $\mathrm{N}(\%)$, mean \pm SD.

Data were compared using the Pearson $\chi^{2}$ test, Fisher exact test, Student $t$ test, or Wilcoxon rank-sum test according to the characteristics of the variables.

off the southern coast of the Korean peninsula with a current population of 670,000 , the number of mutation carriers could reach 67,000 , and they could be at increased risk of stroke or develop other symptoms reported in CADASIL. Long-term impact of harboring pathogenic NOTCH3 variants in seemingly healthy young individuals needs to be investigated further. 


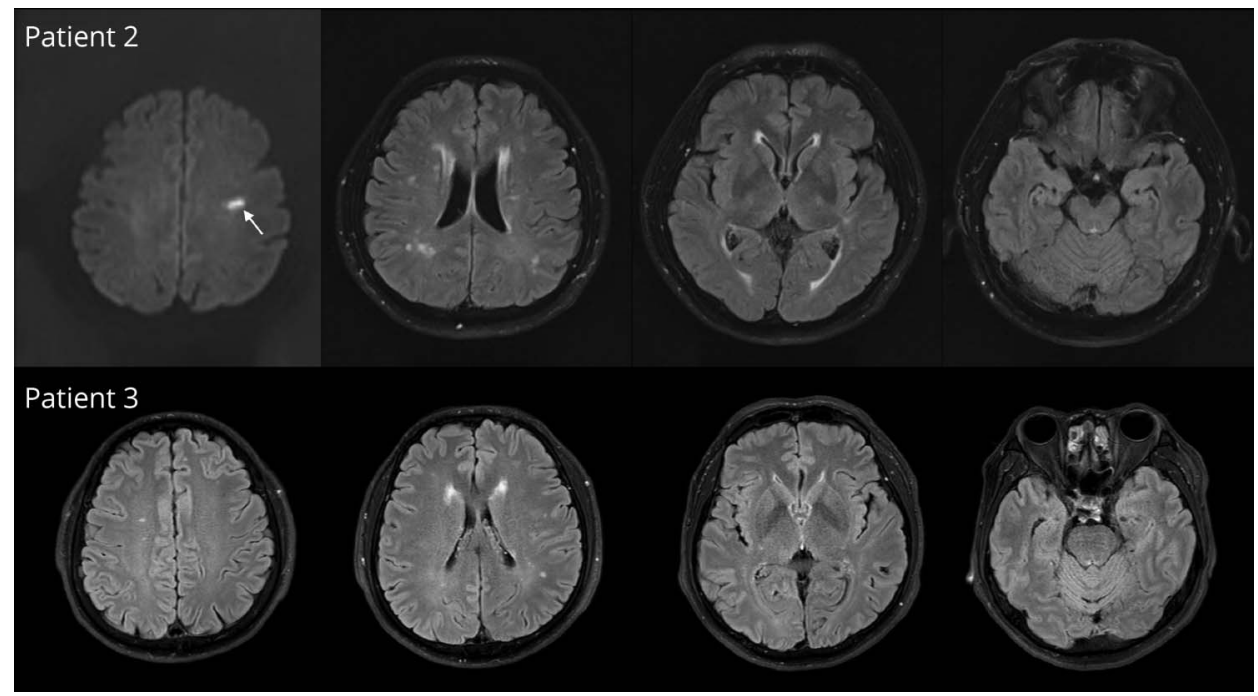

Patient 2 is a 58-year-old man who had had an abrupt onset of mild dysarthria at age 54 years. Diffusion MRI at that time showed a small subacute infarction on the left frontal white matter (arrow) and multiple small white matter hyperintensity lesions on fluid attenuated inversion recovery images. Patient 3 is a 50-year-old man and received a brain MRI examination as a screening health checkup and had a few small subcortical white matter hyperintensity lesions and periventricular white matter lesions.

This study has several limitations. First, because of the limited sample size of the Korean public genome database and the Jeju screening study, this study was underpowered to prove whether the Korean general population has a high prevalence of pathogenic NOTCH3 variants reported in the previous literature. Second, we screened only the 3 most frequently found pathogenic variants in the Jeju screening study. Therefore, we might miss other rare pathogenic variant associated with CADASIL in these 1,000 individuals.

\section{Acknowledgment}

The biospecimens and data used for this study were provided by the Biobank of Jeju National University Hospital, a member of the Korea Biobank Network.

\section{Study Funding}

This work was supported by a research grant from Jeju National University Hospital in 2020.

\section{Disclosure}

Go to Neurology.org/NG for full disclsoures.

\section{Publication History}

Received by Neurology: Genetics June 28, 2021. Accepted in final form October 5, 2021.

\section{Appendix Authors}

\begin{tabular}{lll}
\hline Name & Location & Contribution \\
\hline $\begin{array}{lll}\text { Chul-Hoo } \\
\text { Kang, MD }\end{array}$ & $\begin{array}{l}\text { Department of Neurology, Jeju } \\
\text { National University Hospital, } \\
\text { Jeju National University School } \\
\text { of Medicine, Jeju, Korea }\end{array}$ & $\begin{array}{l}\text { Drafting/revision of the } \\
\text { manuscript for content, } \\
\text { including medical writing for } \\
\text { content; major role in the } \\
\text { acquisition of data; additional } \\
\text { contributions: this author } \\
\text { contributed equally to the } \\
\end{array}$ \\
& manuscript as the first author.
\end{tabular}

Appendix (continued)

\begin{tabular}{|c|c|c|}
\hline Name & Location & Contribution \\
\hline $\begin{array}{l}\text { Young } \\
\text { Mee Kim, } \\
\text { PhD }\end{array}$ & $\begin{array}{l}\text { Department of Biochemistry, } \\
\text { School of Medicine, Jeju } \\
\text { National University, Jeju, } \\
\text { Korea }\end{array}$ & $\begin{array}{l}\text { Drafting/revision of the } \\
\text { manuscript for content, } \\
\text { including medical writing for } \\
\text { content; analysis or } \\
\text { interpretation of data; } \\
\text { additional contributions: this } \\
\text { author contributed equally to } \\
\text { the manuscript as the first } \\
\text { author. }\end{array}$ \\
\hline
\end{tabular}

\begin{tabular}{lll}
\hline $\begin{array}{l}\text { Yang-Ji } \\
\text { Kim, MS }\end{array}$ & $\begin{array}{l}\text { Institute of Medical Science, } \\
\text { Jeju National University, Jeju, } \\
\text { Korea }\end{array}$ & $\begin{array}{l}\text { Major role in the acquisition of } \\
\text { data and analysis or } \\
\text { interpretation of data }\end{array}$ \\
\hline $\begin{array}{lll}\text { Su-Jeong } \\
\text { Hong, MS }\end{array}$ & $\begin{array}{l}\text { Institute of Medical Science, } \\
\text { Jeju National University, Jeju, } \\
\text { Korea }\end{array}$ & $\begin{array}{l}\text { Major role in the acquisition of } \\
\text { data and analysis or } \\
\text { interpretation of data }\end{array}$ \\
\hline $\begin{array}{lll}\text { Do Yoon } \\
\text { Kim, BS }\end{array}$ & $\begin{array}{l}\text { Department of Physiology, } \\
\text { Ajou University School of } \\
\text { Medicine, Suwon, Republic } \\
\text { of Korea; Department of } \\
\text { Biomedical Science, } \\
\text { Graduate School, Ajou } \\
\text { University, Suwon, Republic } \\
\text { of Korea }\end{array}$ & \\
&
\end{tabular}

Hyun Goo Department of Physiology, Study concept or design

Woo, MD, Ajou University School of

PhD Medicine, Suwon, Republic of Korea; Department of Biomedical Science,

Graduate School, Ajou University, Suwon, Republic of Korea

\begin{tabular}{lll}
\hline $\begin{array}{l}\text { Young } \\
\text { Ree Kim, } \\
\text { MD, PhD }\end{array}$ & $\begin{array}{l}\text { Department of Laboratory } \\
\text { Medicine, Jeju National } \\
\text { University School of Medicine, } \\
\text { Jeju, Korea }\end{array}$ & $\begin{array}{l}\text { Major role in the acquisition of } \\
\text { data }\end{array}$ \\
\hline $\begin{array}{l}\text { Joong- } \\
\text { Goo Kim, } \\
\text { MD }\end{array}$ & $\begin{array}{l}\text { Department of Neurology, Jeju } \\
\text { National University Hospital, } \\
\text { Jeju National University School } \\
\text { of Medicine, Jeju, Korea }\end{array}$ & Study concept or design \\
\end{tabular}


Appendix (continued)

\begin{tabular}{|c|c|c|}
\hline Name & Location & Contribution \\
\hline $\begin{array}{l}\text { Jung Seok } \\
\text { Lee, MD }\end{array}$ & $\begin{array}{l}\text { Department of Neurology, } \\
\text { Jeju National University } \\
\text { Hospital, Jeju National } \\
\text { University School of } \\
\text { Medicine, Jeju, Korea }\end{array}$ & Study concept or design \\
\hline $\begin{array}{l}\text { Mi Hee } \\
\text { Kong, MD, } \\
\text { PhD }\end{array}$ & $\begin{array}{l}\text { Department of Family } \\
\text { Medicine, Jeju National } \\
\text { University Hospital, Jeju, } \\
\text { Korea; Department of } \\
\text { Family Medicine, } \\
\text { Jeju National University } \\
\text { School of Medicine, } \\
\text { Jeju, Korea }\end{array}$ & $\begin{array}{l}\text { Major role in the acquisition of } \\
\text { data }\end{array}$ \\
\hline $\begin{array}{l}\text { Hyeon Ju } \\
\text { Kim, MD }\end{array}$ & $\begin{array}{l}\text { Department of Family } \\
\text { Medicine, Jeju National } \\
\text { University Hospital, Jeju, } \\
\text { Korea; Department of Family } \\
\text { Medicine, Jeju National } \\
\text { University School of Medicine, } \\
\text { Jeju, Korea }\end{array}$ & $\begin{array}{l}\text { Major role in the acquisition of } \\
\text { data }\end{array}$ \\
\hline
\end{tabular}

Appendix (continued)

Name Location Contribution

Jay Chol Department of Neurology, Jeju

Choi, MD, National University Hospital,

PhD of Medicine, Jeju, Korea; National University, Jeju, Korea interpretation of data

\section{References}

1. Choi JC. Genetics of cerebral small vessel disease. J Stroke. 2015;17(1):7-16.

2. Narayan SK, Gorman G, Kalaria RN, Ford GA, Chinnery PF. The minimum prevalence of CADASIL in northeast England. Neurology. 2012;78(13):1025-1027.

3. Rutten JW, Dauwerse HG, Gravesteijn G, et al. Archetypal NOTCH3 mutations frequent in public exome: implications for CADASIL. Ann Clin Transl Neurol. 2016;3(11):844-853.

4. Jeon S, Bhak Y, Choi Y, et al. Korean genome project: 1094 Korean personal genomes with clinical information. Sci Adv. 2020;6(22):eaaz7835.

5. Jung KS, Hong KW, Jo HY, et al. KRGDB: the large-scale variant database of 1722 Koreans based on whole genome sequencing. Database. 2020;2020:baz146 doi: 10.1093/database/baz146. Published: March 4, 2020.

6. Wang K, Li M, Hakonarson H. ANNOVAR: functional annotation of genetic variants from high-throughput sequencing data. Nucleic Acids Res. 2010;38(16):e164

7. Lee YC, Chung CP, Chang MH, Wang SJ, Liao YC. NOTCH3 cysteine-altering variant is an important risk factor for stroke in the Taiwanese population. Neurology. 2020;94(1):e87-e96. 


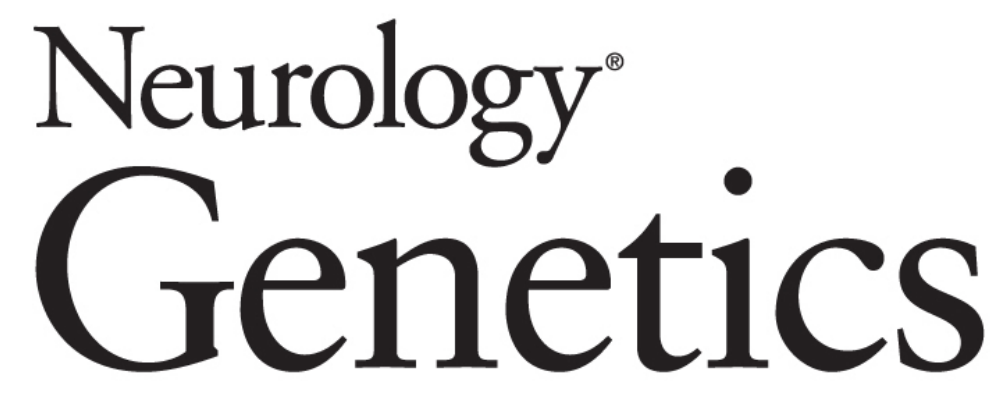

Pathogenic NOTCH3 Variants Are Frequent Among the Korean General Population Chul-Hoo Kang, Young Mee Kim, Yang-Ji Kim, et al. Neurol Genet 2021;7;

DOI 10.1212/NXG.0000000000000639

This information is current as of December 6, 2021

\section{Updated Information \&} Services

References

Citations

Subspecialty Collections

Permissions \& Licensing

Reprints including high resolution figures, can be found at: http://ng.neurology.org/content/7/6/e639.full.html

This article cites 7 articles, 1 of which you can access for free at: http://ng.neurology.org/content/7/6/e639.full.html\#\#ref-list-1

This article has been cited by 1 HighWire-hosted articles: http://ng.neurology.org/content/7/6/e639.full.html\#\#otherarticles

This article, along with others on similar topics, appears in the following collection(s):

\section{CADASIL}

http://ng.neurology.org//cgi/collection/cadasil

Information about reproducing this article in parts (figures,tables) or in its entirety can be found online at:

http://ng.neurology.org/misc/about.xhtml\#permissions

Information about ordering reprints can be found online: http://ng.neurology.org/misc/addir.xhtml\#reprintsus

Neurol Genet is an official journal of the American Academy of Neurology. Published since April 2015, it is an open-access, online-only, continuous publication journal. Copyright Copyright $@ 2021$ The Author(s). Published by Wolters Kluwer Health, Inc. on behalf of the American Academy of Neurology.. All rights reserved. Online ISSN: 2376-7839.

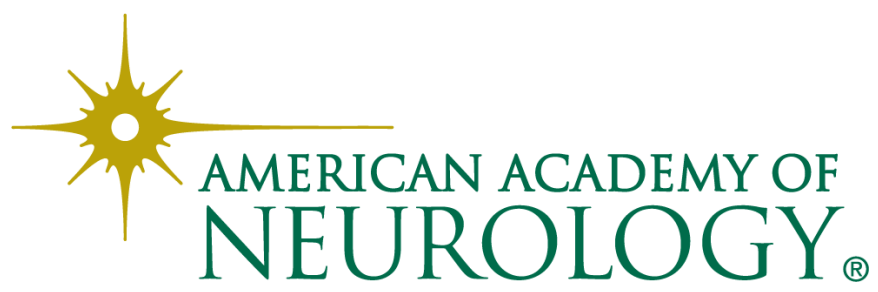

